А. В. Колесник ${ }^{1}$, І. В. Захарченко 2 , П. Г. Берднік ${ }^{3}$

1 Льотна академія Національного авіаційного університету, Кропивницький, Україна

${ }^{2}$ Харківський національний університет Повітряних Сил імені Івана Кожедуба, Харків, Україна

${ }^{3}$ Харківський національний університет імені В. Н. Каразіна, Харків, Україна

\title{
МОДЕЛЮВАННЯ ПРОЦЕСІВ РОЗВИТКУ СИТУАЩІЇ ПРИ ВІДМОВІ ДВИГУНА НА ПОВІТРЯНОМУ СУДНІ В ПОЛЬОТІ
}

\begin{abstract}
Анотація. Предметом вивчення в статті є процеси розвитку ситуації при відмові двигуна на повітряному судні в польоті. Метою $\epsilon$ побудова моделі можливого подальшого розвитку ситуації у випадку відмови двигуна на повітряному судні в польоті. Завдання: статистичний аналіз авіаційних подій, що сталися 3 цивільними повітряними суднами України, причиною яких стала відмова двигуна в польоті, аналіз необхідністі дослідження дій авіаційних спеціалістів в особливих випадках з точки зору прийняття ними своєчасних правильних рішень в умовах зростаючого психоемоційного навантаження. Використовуваними методами $€$ : методи аналізу і синтезу складних інформаційних систем, методи імітаційно-статистичного моделювання. Отримані такі результати. Встановлено, що кількість авіаційних подій, пов'язаних 3 відмовою двигуна не має тенденції до зниження. Встановлено, що додаткове нервово-емоційне навантаження стає на заваді виконання пілотом та авіадиспетчером їх основних професійних функцій. Побудована модель можливого розвитку ситуації при виникненні особливого випадку в польоті - відмові двигуна на повітряному судні для іiї подальшого використання при практичній підготовці авіадиспечерів до дій в особливих випадках. Висновки. Напрямком подальших досліджень є розробка та побудова системи підтримки прийняття рішень для удосконалення технології роботи авіадиспетчера управління повітряним рухом
\end{abstract}

Ключ ов і сл ов а : відмова двигуна, особливі випадки, зліт, посадка, пілот, авіадиспетчер.

\section{Вступ}

Постановка проблеми у загальному вигляді. Досягнення ефективності авіаційних перевезень можливо лише при забезпеченні високого рівня безпеки польотів. В наш час дуже гостро постає проблема забезпечення безпеки польотів в особливих випадках, причинами яких є відмови авіаційної техніки. В значній мірі цьому сприяє експлуатація літальних апаратів, двигунів та комплектувальних виробів, що мають подовжений ресурс або тих, знаходяться на граничній межі термінів експлуатації. Крім того, важливим фактором також є орнітологічна обстановка в районі аеродрому.

При виникненні особливого випадку дії авіадиспетчера можуть відрізнятися від встановленого алгоритму роботи. При цьому виникає необхідність виконувати нестандартні дії, проявляти самостійність та ініціативу в умовах зростання психоемоційного навантаження.

При виникненні такого особливого випадку, такого як відмова двигуна (двигунів) на повітряному судні (ПС) під час виконання польоту для прийняття своєчасних правильних рішень пілот і авіадиспетчер повинні володіти належним рівнем спеціальних знань та практичних навиків управління. Професіоналізм диспетчера, достовірність та своєчасність наданої ним інформації в значній мірі можуть визначити наслідок такої ситуації.

Виникає потреба розробки програмного продукту, який би дозволив підвищити рівень безпеки польотів і ефективності роботи диспетчерів щодо їх дій при виникненні ОВП (особливий випадок в польоті), такого як, відмова двигуна на ПС (повітряне судно). На початковому етапі вирішення даного завдання необхідно здійснити моделювання можли- вого розвитку ситуації при виникненні особливого випадку в польоті.

Мета статті - побудова моделі можливого подальшого розвитку ситуації у випадку відмови двигуна на повітряному судні в польоті

Аналіз останніх досліджень і публікацій. Вивчення літературних джерел показало, що аналіз дій авіадиспетчера в нестандартних ситуаціях, пов'язаних з ОВП - відмова двигуна на ПС в польоті $є$ в працях деяких авторів (Ю.Сікірда, С. Мельниченко, Т.Шмельова та ін). Але вони мають лише інформаційний характер і не вказують шляхи практичного використання матеріалів в навчальному та робочому процесах.

Також існує ряд наукових робіт, присвячених підготовці пілотів щодо їх дій в тому чи іншому ОВП. Наприклад в роботі [1] досліджено рух багатомоторного ПС з неповною тягою в результаті відмови одного чи більше двигунів, а також розраховано ймовірнісні характеристики польоту літака $з$ двигуном, що відмовив. Однак більша частина роботи присвячена аналізу дій та рекомендаціям екіпажу та пілоту при виникненні відмови двигуна на ПС. Питання, присвячені проблемам, які виникають в авіадиспетчерів в таких ситуаціях не розглядаються. Інформації та літератури стосовно рекомендацій диспетчеру щодо його дій при виникненні відмови двигуна на ПС в польоті недостатньо, тому доцільно розглянути й більш детально вивчити процес роботи диспетчерів у таких випадках.

При написанні даної статті корисною була інформація 3 таких основних джерел статистичної інформації як [2], сайт Aviation Safety Network [3] (база даних з авіаційної безпеки: статистичні дані за різними типами ПС починаючи з 1943 року), сайт European Aviation Safety Agency (ведеться збір да- 
них, дослідження по БП в Європі та світі) [4], ICAO Accident Indent Data Reporting system (База даних Міжнародної організації цивільної авіації); Сайт Airdisaster.com (незалежне Інтернет видання: дані по авіаційним подіям, деталізована статистика по рокам, регіонам, авіакомпаніям, типам ПС) [5], База даних NTSB [6] (детальний статистичний аналіз авіаційних подій, що сталися по причині відмови двигуна на ПС).

\section{Основна частина}

Статистичний аналіз авіаційних подій показує, що відмова авіаційного двигуна займає значне місце серед інших причин авіаційних подій (7,5\%) [6].

В наш час існує достатньо велика кількість робіт (Люлька А.М., Кузнецов Н.Д., Мікулін А.А.,
Ізотов С.П., Климов В.Я. та ін.), в яких розглянуто причини відмови двигунів, а також, насамперед, поводження при цьому диспетчера й екіпажа на етапах злету та посадки. Ці два етапи польоту вважаються найбільш критичними в авіації, що пов'язано з тим, що вони виконуються поблизу землі й на малих швидкостях, коли ефективність аеродинамічних органів управління і несучих поверхонь мала. Отже резерву часу та простору для виправлення навіть незначних помилок просто немає. Однак не менш важливим етапом польоту є горизонтальний політ, під час якого також мають місце катастрофічні ситуації.

На основі статистики відмов авіаційних двигунів [3] на різних етапах польоту за останне десятиліття побудовано діаграму (рис. 1).

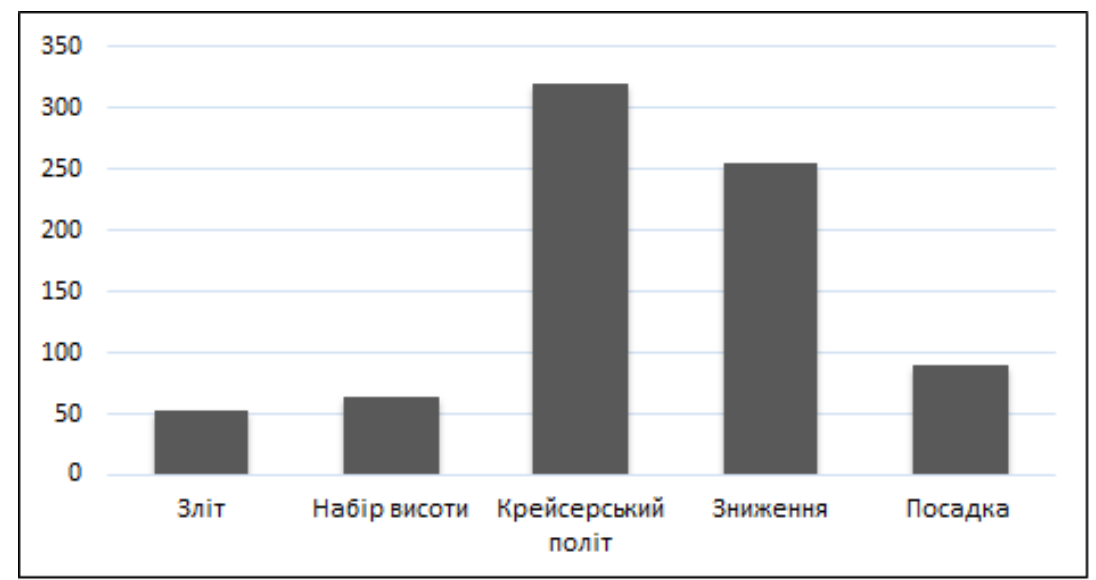

Рис. 1. Розподіл кількості випадків відмов двигунів за етапами польоту ПС

3 наведеної діаграми видно, що етап горизонтального польоту (крейсерський політ) $є$ не менш важливим етапом при аналізі випадків відмов двигуна.

Далі наведено аналіз стану безпеки польотів за результатами розслідування подій і інцидентів за останні роки, що сталися з цивільними повітряними суднами України, які внесені до Державного реєстру цивільних ПС.

В табл. 1 наведено відомості щодо кількості відмов двигунів, що мали місце 3 початку 2016 року по перше півріччя 2019 року з повітряними суднами України [7-10].

Таблиия 1 - Розподіл кількості відмов двигунів за роками

\begin{tabular}{|c|c|c|c|c|}
\hline Роки & $\mathbf{2 0 1 6}$ & $\mathbf{2 0 1 7}$ & $\mathbf{2 0 1 8}$ & 1 пів. 2019 \\
\hline $\begin{array}{c}\text { Кількість відмов } \\
\text { двигуна }\end{array}$ & 3 & 9 & 7 & 7 \\
\hline
\end{tabular}

Серед видів відмов, що траплялись 3 авіаційними двигунами слід зазначити наступні: повна відмова двигуна, падіння потужності, самовільне вимкнення, зниження тиску масла в двигуні, пошкодження двигуна внаслідок попадання птахів, перевищення експлуатаційних обмежень параметрів двигуна.

Для більш коректної оцінки результатів проведеного аналізу випадки відмов двигуна слід розгля- дати у відношенні до загальної кількості авіаційних подій та інцидентів, які сталися за період, що аналізується (рис. 2). Проаналізувавши кількість N зареєстрованих відмов з 2016 по 2019 роки [7-10] (рис.2) бачимо, що тенденції до зменшення кількості випадків, пов'яза-них з відмовою двигуна не спостерігається. Але за той самий період в Україні збільшилась кількість годин загального нальоту (рис. 3).

Отже статистику випадків відмов авіаційних двигунів в польоті слід аналізувати 3 урахування загальної кількості льотних годин на рік.

3 відношення $\mathrm{N}$ відмов авіаційних двигунів на ПС до кількості М годин нальоту за кожен рік, маємо середню кількість відмов авіаційних двигунів на 100 тис. годин нальоту (К) (табл. 2).

Таблиця 2 - Середня кількість відмов авіаційних двигунів 100 тис. годин нальоту

\begin{tabular}{|c|c|c|c|c|}
\hline Роки & $\mathbf{2 0 1 6}$ & $\mathbf{2 0 1 7}$ & $\mathbf{2 0 1 8}$ & 1 пів. 2019 \\
\hline К & 1,1 & 3,1 & 2,3 & 4,7 \\
\hline
\end{tabular}

Побудуємо лінію тренду, яка графічно відображає тенденції даних і прогнозує їхні подальші зміни. Лінія тренду має наступний вигляд (рис. 4). Бачимо, що незважаючи на те, що конструктори постійно удосконалюють надійність і тривалість експлуатації авіаційних двигунів, кількість відмов має тенденцію до зростання. 


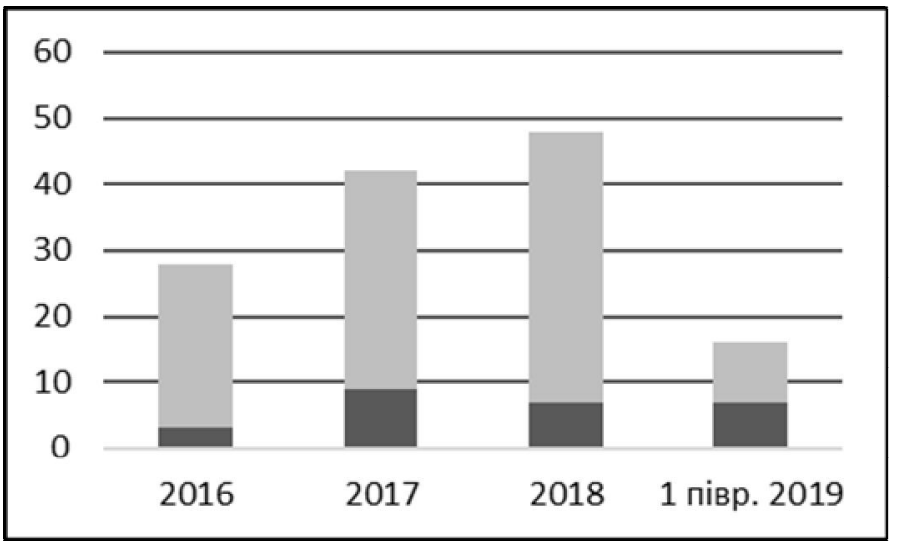

Рис. 2. Кількість зареєстрованих випадків відмов авіаційних двигунів ПС цивільної авіації України (по роках)

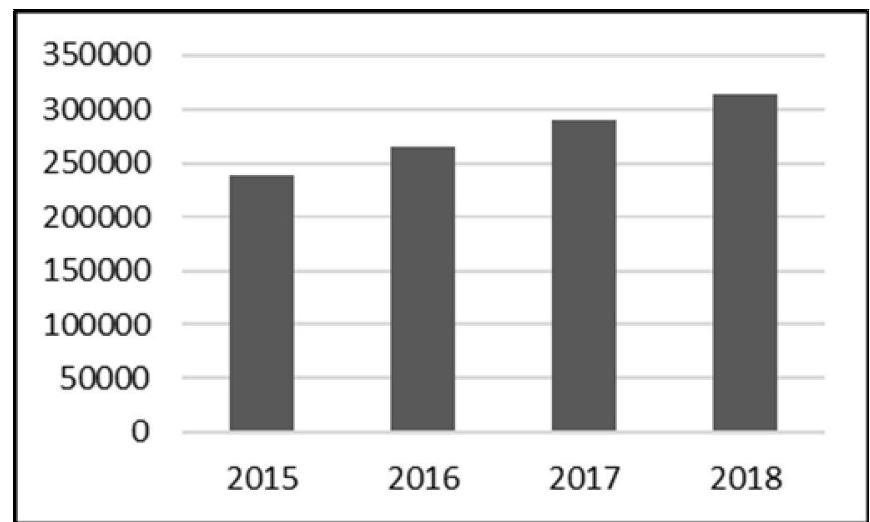

Рис. 3. Кількість годин загального нальоту ПС цивільної авіації України ( по роках)

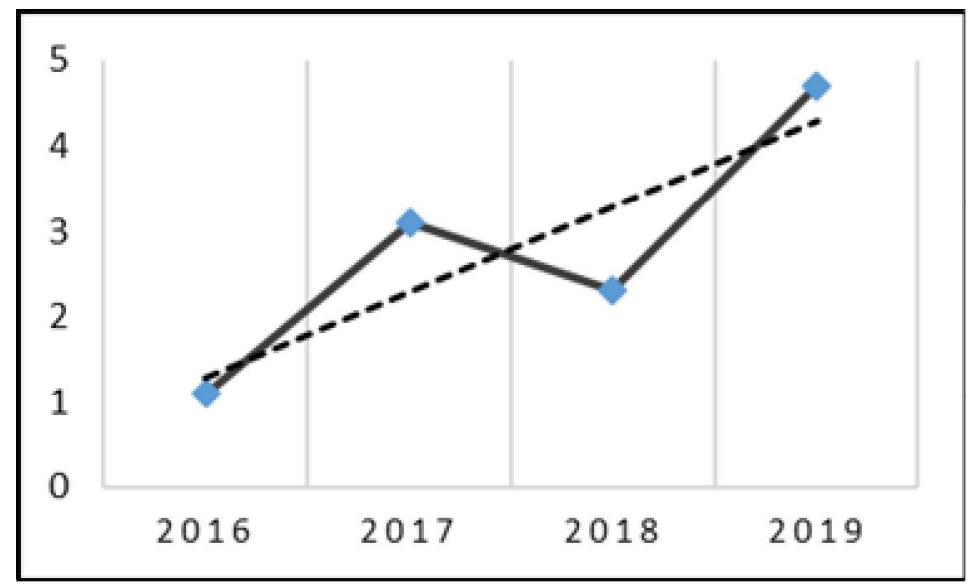

Рис. 4. Динамічний аналіз рівня безпеки польотів по ймовірності авіаційної події «Відмова двигуна на ПС»

3 наведених вище результатів аналізу можна зробити висновок, що проблема відмови авіаційних двигунів на сучасному етапі являється достатньо актуальною.

Остаточне рішення відносно подальшого продовження польоту при появі особливого випадку у польоті нормативними документами покладено на командира ПС, але авіадиспетчер має постійно бути готовим до видачі відповідної рекомендації не лише щодо дій екіпажу в даний момент, але й щодо прогнозування подальшого розвитку ситуації, щодо переходу з аварійної в катастрофічну.
Згідно із статистикою [11], в подібних ситуаціях у 30-45\% випадків пілоти не можуть прийняти жодного рішення через психологічний стрес, в 2535\% випадків вони приймають неадекватні рішення.

Але не можна забувати, що в критичних ситуаціях, нервово-емоційна напруга авіаційних диспетчерів також різко зростає:

- 20\% з них не можуть оцінити ситуацію, і тому не приймають жодного рішення,

- 10\% - приймають неправильні рішення,

- 22\% - впадають в «ступорозний» стан і не діють, 
- 34\% - виконують непотрібні дії і лише погіршують ситуацію [11].

Необхідність при цьому надати відповідну допомогу викликає додаткову нервово-емоційну напругу і стає на перешкоді виконання диспетчером його основних професійних функцій.

Проблема професійної підготовки авіадиспетчерів в екстремальних польотних ситуаціях в наш час придбала особливого значення у всіх країнах, у тому числі і в Україні.

Удосконалення оцінки ситуації, методів та алгоритмів прийняття рішень в умовах відмови двигуна $\epsilon$ актуальною та сучасною задачею дослідження.

Тому доцільно було побудувати модель можливого подальшого розвитку ситуацій у випадку відмови двигуна на ПС в польоті (рис.5).

Для побудови даної моделі було використано інформацію із доступних баз даних по подіям, інцидентам та авіаційних катастрофам, що трапилися раніше $з$ повітряними суднами.

Дана інформація збирається й аналізується, міжнародними й національними організаціями, а також окремими авіакомпаніями.

Було проаналізовано 100 випадків відмови авіаційних двигунів й на цій основі в процентному співвідношенні висвітлено можливість розвитку тієї чи іншої ситуації. Отже у процентному співвідношенні кількість катастрофічних ситуацій і кількість випадків вдалого завершення польоту складає 25$30 \%$, тобто майже рівні. Випадки, коли польоти повітряного судна $з$ відмовою двигуна завершуються 3 різного роду пошкодженнями конструкцій літака, чи, навіть, наявності постраждалих, досягають майже половини (50\%) випадків. Це, в свою чергу, значно погіршує рівень безпеки цивільної авіації.

Тому подальше вивчення такого особливого випадку в польоті, як відмова авіаційного двигуна і насамперед прогнозування подальшого розвитку особливої ситуації в польоті, якщо вона сталася, являється достатньо актуальним не тільки для екіпажу повітряного судна, але й для майбутніх та діючих авіадиспетчерів. Саме своєчасні та правильні рекомендації екіпажу, надані авіаційним диспетчером, значно сприяють вдалому вирішенню проблеми.

Запропоновану модель (рис. 5) можливого подальшого розвитку ситуацій у випадку відмови двигуна на повітряному судні в польоті в подальшій роботі буде використано при розробці та побудові системи підтримки прийняття рішень авіадиспетчеpa «HELP».

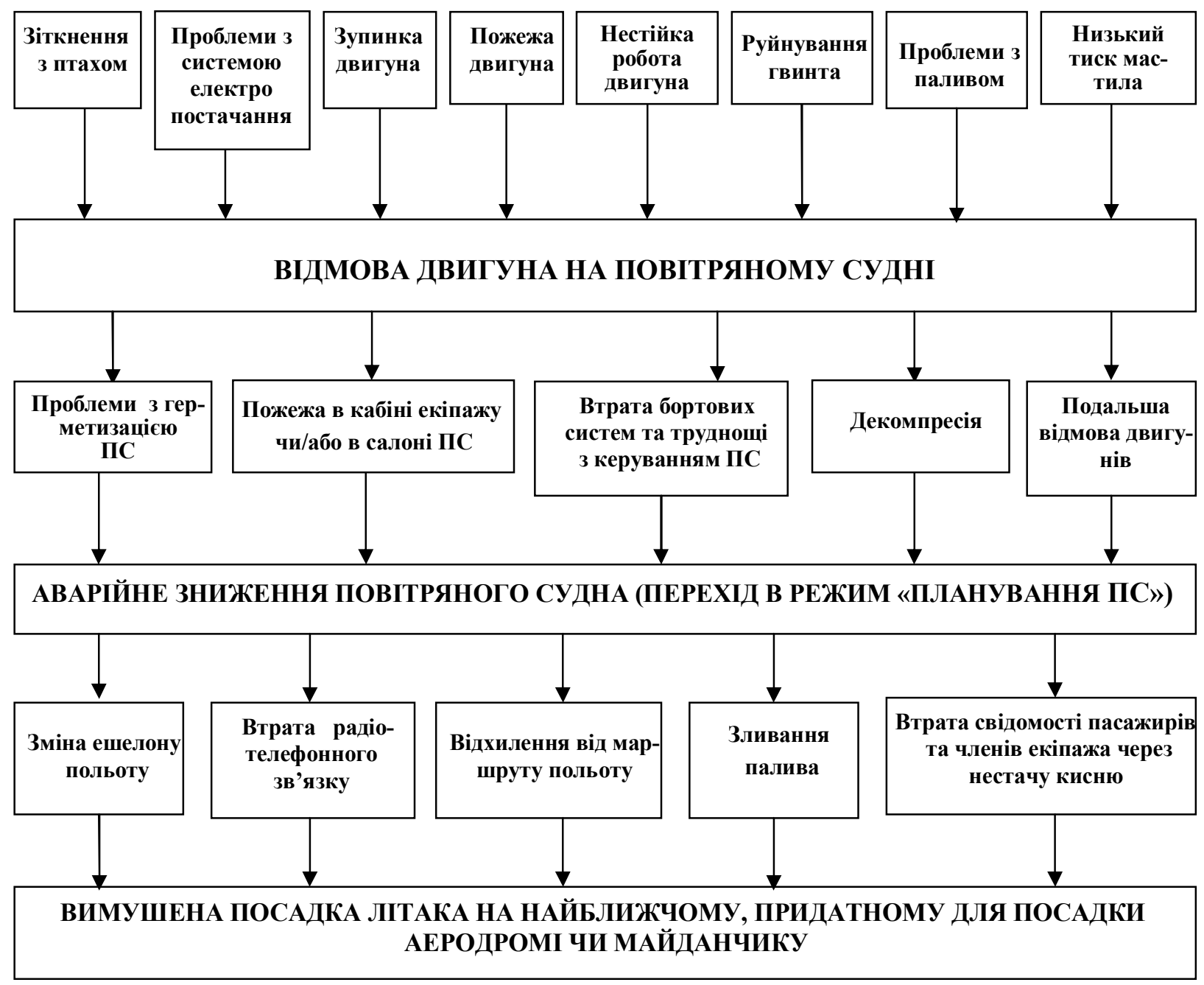

Рис. 5. Модель можливого подальшого розвитку ситуації при виникненні ОВП - відмова двигуна на ПС в польоті 
Така система дозволить значно зменшити час, необхідний екіпажу та авіадиспетчеру на визначення оптимального варіанту завершення польоту в разі виникнення позаштатної ситуації - відмова двигуна на ПС в польоті з урахуванням показника ймовірності вдалого завершення польоту при оцінці вибору потенційного місця посадки.

\section{Висновки і напрямки подальших досліджень}

Результати аналізу авіаційних подій дали змогу зазначити головне протиріччя: між зростаючою роллю диспетчерів управління повітряним рухом в підвищенні безпеки польотів й відсутністю науково обгрунтованої методики навчання їх на основі аналізу авіаційних подій, пов'язаних з особливими випадками в польоті.

Проведено статистичний аналіз авіаційних подій, що сталися 3 цивільними повітряними суднами
України, причиною яких стала відмова двигуна в польоті. В результаті даного аналізу встановлено, що кількість авіаційних подій, пов'язаних 3 відмовою двигуна не має тенденції до зниження, що свідчить про актуальність даної проблеми.

Проведено аналіз прийняття рішень командирами повітряних суден та авіадиспетчерами у особливих випадках в польоті. Встановлено, що додаткове нервово-емоційне навантаження стає на заваді виконанню пілотом та авіадиспетчером їх основних професійних функцій.

У роботі побудовано модель можливого подальшого розвитку ситуацій у випадку відмови двигуна на повітряному судні в польоті. Отримані результати дозволяють розробити рекомендації по вдосконаленню технології роботи авіадиспетчера управління повітряним рухом при виникненні особливого випадку в польоті - відмова двигуна на ПС, а також створити систему підтримки прийняття рішень.

\section{СПИСОК ЛІТЕРАТУРИ}

1. Галлай М. Л. Полет самолета с неполной и несиметричной тягой / Галлай М. Л. - М.: Машиностроение, 1970 - $192 \mathrm{c}$.

2. Неделько С.Н. Оценка эффективности информационной поддержки операторов автоматизированных систем обслуживания воздушного движения / С.Н. Неделько, В.Н. Неделько // Вісник КМУЦА. - К.: КМУЦА, 1999. - № 2. C. $184-186$

3. База даних з авіаційної безпеки // Режим доступу: http://aviation-safety.net/index.php.

4. Европейское агентство по безопасности полетов // Режим доступу: http://easa.europa.eu.

5. База даних по авіаційним катастрофам США // Режим доступу: http://www.ntsb.gov/investigations/summary/AAR0003.html.

6. База даних авіаційних подій // Режим доступу: http://www.aviation-accidents.net/

7. Аналіз стану безпеки польотів за результатами розслідування авіаційних подій та інцидентів 3 цивільними повітряними суднами україни та суднами іноземної реєстрації, що сталися у 1 півріччі 2019 року // Режим доступу: http://www.nbaai.gov.ua/uploads/pdf/2019.pdf.

8. Аналіз стану безпеки польотів за результатами розслідування авіаційних подій та інцидентів 3 цивільними повітряними суднами україни та суднами іноземної реєстрації, що сталися у 2018 році // Режим доступу: http://www.nbaai.gov.ua/uploads/pdf/Analysis2018.pdf

9. Аналіз стану безпеки польотів за результатами розслідування авіаційних подій та інцидентів 3 цивільними повітряними суднами україни та суднами іноземної реєстрації, що сталися у 1 півріччі 2017 році // Режим доступу http://www.nbaai.gov.ua/uploads/pdf/Analysis 2017.pdf

10. Аналіз стану безпеки польотів за результатами розслідування авіаційних подій та інцидентів 3 цивільними повітряними суднами україни та суднами іноземної реєстрації, що сталися у 1 півріччі 2016 року // Режим доступу: http://www.nbaai.gov.ua/uploads/pdf/Analysis_2016.pdf

11. Лейченко С. Д. Человеческий фактор в авиации / С. Д. Лейченко, А. В. Малишевский. - Кировоград, 2006. Кн. 1. -480 c.

\section{Modeling of the processes of developing situations for aircraft engine failure in flight}

A. Kolesnik, I. Zakharchenko, P. Berdnik

Abstract. The subject matter of the article is the development of the situation when the engine fails in an aircraft. The goal is to build a model of the possible further development of the situation in case of engine failure in an aircraft in flight. The tasks are: a statistical analysis of aviation events that occurred with civil aircraft of Ukraine, the cause of which was the engine failure in flight; analysis the need to study the actions of aviation specialists in special cases from the point of view of making timely, correct decisions in the face of a growing psychoemotional load. The methods used are: methods of analysis and synthesis of complex information systems, methods of simulation and statistical modeling. The following results were obtained. It has been established that the number of accidents related to engine failure does not tend to decrease. It has been established that the additional neuro-emotional load impedes the fulfillment by the pilot and air traffic controller of their basic professional functions. Model of possible situation development in case of a special case in flight - engine failure on an aircraft is built for its further use in practical training of air traffic controllers for action in special cases. Conclusions. The results obtained allow us to develop recommendations for improving the technology of operation of the air traffic controller air traffic control in case of a special case in flight - engine failure on the aircraft, as well as to create a decision support system. The direction of further research is development and construction of a decision support system to improve the operation of the air traffic controller.

Keywords: engine failure, special cases, takeoff, landing, pilot, air traffic controller. 